\title{
Collective internationalization strategy, dispersed information, and entrepreneurial orientation interactions
}

\author{
Hamid Etemad ${ }^{1}$ \\ Published online: 5 March 2020 \\ C) Springer Science+Business Media, LLC, part of Springer Nature 2020
}

\section{Introductions}

The year 2020 is ushering in the eighteenth anniversary and the volume eighteenth of the Journal of international Entrepreneurship. This volume will continue the journal's policy of publishing refereed articles that address the frontiers of entrepreneurial internationalization or international entrepreneurship. This article extends, and further builds on, the discussion of influential theoretical and managerial concepts in the extant literature and other advances with significant theoretical implications and managerial application for entrepreneurial firms' internationalization.

This issue's overriding theme is relatively broad as it starts with the very basic question of what incentives and rationales motivate smaller entrepreneurial firms' internationalization. Given the entrepreneurial character and orientation of these firms (Etemad 2015a, b, DeClercq et al. 2005, Deligianni et al. 2015, Lumpkin and Dess 1996), their constrained resources, and international markets' higher risks and uncertainties, internationalization does not appear as a sound strategy at the outset; and yet even many embryonic firms, such as Born Globals (e.g. Knight and Cavusgil 2004), Early Internationalizing Firms (e.g. Romanello and Chiarvesio 2019), International New Ventures (e.g. McDougall et al. 1994; McDougall and Oviatt 2000, McDougall et al. 1994, Oviatt and McDougall 1994, 1995, McDougall 1989), and Rapidly Internationalizing Enterprises (e.g. Etemad and Wu 2013; Keen and Etemad 2011, 2012), rush to international market and achieve competitive positions there. Following their achievements in terms of growth, incremental employment, revenues, and profits, many countries have re-oriented their public policies to assist these firms' quest and benefit from their international involvements. However, and due to their entrepreneurial orientation and entrepreneurial practices (Covin and Slevin 1989, 1990, 1991), these firms tend to find, or formulate, different justifications for their internationalization and

Hamid Etemad

hamid.etemad@mcgill.ca

$1 \quad$ McGill University, Montreal, Canada 
adopt a variety of diverse strategies; each of which appear to have strong internal entrepreneurial support; and most of which experience results that are consistent with the firm's a priori expectations as well as according to their strategic orientation and corporate cultural values (Morgan and Strong 2003). This brief discussion points to a complex inter-relationship amongst multiple sets, or families, of influential factors, including, motivations for internationalization, strategic approach to, and evolutionary internationalization implementation processes as well as expectation of higher outcomes over time and across international markets.

This article will also draw on fundamental concepts of entrepreneurship and international entrepreneurship, discussed in this journal, and elsewhere, for exploring how they have evolved, and are still evolving, internationally over time to stimulate further advances in the field. In particular, we return to the concept of international entrepreneurial orientation (IEO) in relation to the entrepreneurial firms' less-explored pattern of evolutions across time and locations with potentially profound impacts on a firm's increasing extent of internationalization and its consequent financial performance and profitability. As internationalization exposes the firm to diverse embedding environments (Granovetter 1985) with differing contextual impacts, corresponding decisions defy routinized, or standardized, procedures, which in turn require more-detailed and nuanced information to avoid exposure to higher uncertainties and operational risks. Consequently, these firms need highly adapted strategies, based on equally adapted methodologies for exploring their specific markets.

The constituent components of these firms' decisions comprise entrepreneurial, marketing, and strategic orientations (Hong et al. 2013; Rodriguez Cano et al. 2004) that affect their criteria for market selection, entry mode into the market, and well-adapted marketing plans, including corresponding adaptation and innovation provisions for each of the local foreign markets. ${ }^{1}$ Similar arguments are applicable to the impact of time and timing on the various aspects of internationalization, as internationalization is both a time-dependent and an evolutionary phenomena, as organizations learn (Gnizy et al. 2014) and evolve overtime. Logically, such evolutions push the firms to higher stages in its own life cycle as well as advancing its products' (and services') through higher stages in their respective life cycles (Etemad 2015b) for fitting better into their markets and delivering higher values to their customers in order to remain competitive across markets and over time. Naturally, all life cycles have carryover effects from the earlier stages to the next and possibly throughout the entire life cycle (Etemad 2018). Stated briefly and differently, entrepreneurially internationalizing firms are expected to approach internationalization differently, due mainly to their evolving orientations and recognition of rapidly evolving customers and markets in the increasingly competitive international markets, where a large number of firms of different sizes and orientations compete for higher sales and international revenues as hinted above and will be further expanded below.

\footnotetext{
${ }^{1}$ It is noteworthy that international markets are reflective of their respective environments. They are neither monolithic nor similar to a firm's home market. Therefore and from the internationalizing firm's perspective, each market needs to be viewed as an independent foreign local market. Therefore, cross-sectional methodologies need to include sufficient control variable to account for the local foreignness (e.g., Hymer 1960; Zaheer 1995) differences.
} 
The main aims and structure of this article The main aim of this article is to present an overriding thematic discussion to relate different issues discussed in the issue in order to further explore and elaborate on their interactive and overall impacts. In light of the above introductory arguments, a brief highlighting and examination of issues discussed in other articles of this issue are presented in part II of this article. Part II will also point out the mutual and complementary relations amongst the next four articles in order to contribute to our collective understandings and encourage, if not stimulate, advancing the frontiers of research and theory in particular and entrepreneurial internationalization in general. Discussions in part III are presented next. Conclusions and implications are presented at the end.

\section{Further developments of concepts related to article in this issue}

This part starts with the basic question of motivation behind entrepreneurial internationalization and ends with discussion of issues involving operational, strategic, and theoretical aspects. The second article in this issue is authored by Eini Haaja of the University of Turku's School of Economics and is entitled as: "Why do some SMEs engage in joint internationalisation and others do not? Exploring the role of mental images in collective international opportunity recognition". The research for answering the above deceptively simple question revealed a relatively more complex phenomena than expected, involving a set of influential and interactive factors in the participating entrepreneurs' cognitive and mental images as well as their inter-relationship that are discussed in some length in the article.

Generally, international markets offer the opportunity of reaching larger global markets than any national market, which in turn, offer vast possibilities, including diversification, growth, learning from and with others (DeClercq et al. 2005; Gnizy et al. 2014), scale-economies, and a path for achieving other rewarding outcomes, such as higher performance. However, the long-standing practice and documented scholarly evidence point to a Janus face behind internationalization - i.e. there are dark hazards against its bright benefits. Except for minority of instances, internationalization is not the low-hanging fruits that are readily available for the willing passer-by to pick and enjoy with no toil or risks. Actually, international market opportunities are not readily and freely available, nor can they be exploited effortlessly. The extensive literature of opportunity recognition has identified challenges, costs, and discomfort, if not losses, associated with risks and uncertainties of entering and operating in international markets (e.g. see the special issue of Journal of International Entrepreneurship on international opportunities, Volume 13 (2015) and also Etemad 2015a). Collectively, they can fall into the challenging categories of omissions (or oversight) and commissions (or misplaced and mistaken actions).

The former is usually a symptom of dispersed, fragmented, and thus incomplete information (Dew et al. 2003), pointing to the potential discrepancies between the information received and the true demand in a foreign local market, as some local agents may not have disclosed information about their true needs to avoid higher transaction costs (Williamson 1975). Similarly, some supplying agents may have held information regarding their actual or potential supplies to maintain higher prices. Dispersed nature of information may mask and possibly obscure the true nature of true 
supplies and the overall demand, especially when some information, or its subsets, are deliberately withheld. As a result, information set, or its subsets, is likely to be missing the particular information that, for example, a supplier needs in order to recognize the presence of sufficient demand and identify it as a potentially rewarding market opportunity to be exploited. A similar condition may exist regarding the supply side. These are not due to unavailability of information at the source, but are due mainly to opportunistic behaviour of some agents withholding information resulting in asymmetry of information (Akerlof 1970) at a point in time. Opportunistic behaviour and asymmetry of information usually add to the transaction costs if transactions are consummated. They may alternatively lead to forgoing opportunities when a party withdraws from further involvement. Stated differently, dispersed information can give rise to the perception of inadequate demand in a particular market for supplies of $\operatorname{SME}(\mathrm{s})$ aspiring to sell them there. ${ }^{2}$

The issue of dispersed information can be resolved by, for example, providing incentive for true information to be pooled together, so that the possibility of empty, or sparsly populated, intersecting sets are likely to decrease, or even disappear completely. The above discussion points to the critical importance of assessing the nature of information and its providers in order to acquire the most complete and reliable information regarding the issues at hand. As hinted earlier, the ex-ante expectations of potential parties in a transaction can raise the ex-post cost of the transaction to the party unaware of the other party's opportunistic behaviour. Therefore, an important challenge of international market opportunity identification is to ensure that the requisite information is as complete, as reliable, as transparent, and as possibly void of opportunistic behaviours as possible in order to avoid dismissing the true opportunity (i.e. omission or oversight).

The latter is the commission of subjective perception, or the incomplete cognition (Renkoa and Freeman 2017), of the true opportunity by entrepreneurs and entrepreneurial firms unaware of the fragmented, disperse, and possibly misleading information and thus perceiving it as the mismatching of supplies and corresponding demand, leading to their mistaken perception of no opportunity as opposed to low demand due to missing information, or the possibility of fragmented and dispersed information, as discussed earlier. Therefore, information asymmetry between the information subset(s) available to the transaction parties may lead to wrongful commissioning of particular actions.

As discussed earlier, such information asymmetry can mask, if not obscure, the challenge of seeing true and the full information set for identifying the worthy opportunity meriting exploitation, which clearly point to the two prominent necessary conditions in international opportunity identification and exploitation: (i) The information indicating the presence of exploitable opportunity and (ii) the sufficient requisite resources and motivations for exploiting the opportunity fruitfully.

Even when the information discrepancies are removed, many may routinely oversee the information or not recognize its potent content, while others may perceive the opportunity, but not pursue them due to lack of resources, or their perception of exploitation complexities adversely impacting their constrained resources, time, and

\footnotetext{
${ }^{2}$ In the set terminology, this is an unacceptable intersection between the two demand and supply information subsets pointing to the absence of an attractive opportunity (e.g., when there is an empty inter-section or not a densely populated overlap between the demand and supply information sets). Therefore, the withholding of information, which is similar to information asymmetry between potential buyers and suppliers, adds to the transaction costs and introduces inefficiencies that generally harm smaller firms than the larger ones.
} 
attention from other promising alternatives. The above discussion points to the advantages of joint opportunity recognition and exploitation, entailing collaboration, pooling of capabilities, information, knowledge, and resources for conducting deliberate joint search in attaining the most complete information (i.e. to avoid dispersed information phenomenon or opportunistic behaviour) and undertaking the challenge of exploiting it collectively (i.e. to generate sufficient motivation, capabilities, and resources to meet challenges), especially when the opportunity exploitation is expected to be complex, resource-intensive, and time-consuming, which a typical entrepreneur or smaller firm may not readily have or cannot easily commit.

Logically, a pooling of information subsets held (or acquired) by different interested agents can lead to a more realistic portrayal of the subject at hand (e.g. reveal the true nature of demand in a foreign market) and may even facilitate the formation of a denser network of collaborating firms. They can not only integrate their dispersed information to form a denser information set but they can also share their perceptions and pool their resources together for increasing their chances for exploiting the potential opportunity successfully. Similarly, collaborating members' divers dynamic capabilities (Pisano 2015; Teece et al. 1997; Teece 2014) may better mitigate opportunity's inherent risks than what each firm could do alone by acting on its own. Within such a context, one would expect entrepreneurially oriented and especially smaller and resourceconstrained SMEs to seek collaboration for both collaborative opportunity recognition and collective opportunity exploitation.

However, as indicated earlier, the research behind the above article points to potential complexities not articulated previously. For example, the article points to many other factors and forces, including management of interactions amongst the collaborating entrepreneurs and firms for the sharing of their information and joint deliberation of their pooled information for collective actions. Naturally, for collective exploitation, collaborators must arrive at a cohesive strategic action based on their mental image and perception of opportunity that necessarily involves compromises in their a priori positions and merging of potentially diverse strategies to formulate a synergic (Dana et al. 2001), and possibly symbiotic (Etemad et al. 2001), joint action.

The actual context of this research may have influenced the nature, and possibly the findings, of this research. The study interviewed 20 representatives, mostly CEOs, of Finnish SMEs in Maritime Industries that jointly explored collective opportunity exploitation in Norway and Russia. Denmark, Netherlands, Norway, and Sweden are Finland's close Scandinavian neighbouring countries. These counties have historically shared similar socio-cultural values, and thus have had closer psychic and geographic distances that are conducive to their preferences for internationalizing in the Scandinavian region. Although Russia is not a Scandinavian country, it is Finland's contiguous neighbour and its relations with Finland has a long-standing history that may have contributed to the Finnish managers' perception of acceptable operational risk due to their shared perspectives that Finnish entrepreneurial smaller firms could collaborate with their Russian counterparts. These shared perceptions may have facilitated the formation of similar cognition of opportunities and their consequent sharing of the entrepreneurial mind-sets for undertaking successful collective actions.

Although this research has paved the road for further collaboration and collective actions of diverse types, the question of if entrepreneurs (or firms) with highly different socio-cultural and economic orientations (or different corporate cultural and value 
systems), and possibly from around the world, could, if not should, collaborate to arrive at a collective cognition of opportunities and joint exploitation deserves further research. Similarly and as discussed earlier, the a-priori expectation of risk and uncertainties deserve further objective assessment to determine if the blurred opportunity and higher perceived risks are associated with Ackerlofian information asymmetry (Akerlof 1970) and dispersed information (Dew et al. 2003) or are due to the Knightian longer term and structural uncertainties (e.g. Foss 1993; Langlois and Cosgel 1993; Knight 1957).

The third article complements the previous one from a different, but related, perspective. It starts where the second article left off. It is authored by Virginie Gallego-Roquelaure and is entitled as: "The emergence process of an international network of SMEs and the evolution of the leader's role". At least four dominant themes of this research need to be further highlighted.

First, the article reports the desire of certain entrepreneurial leaders to form a rich inter-personal network of SME leaders. The extensive literature of internationalization through networks (e.g. Johanson and Vahlne 2010; Johanson and Mattsson 1987) has documented ample support for the incremental advantages of networks in general, and even higher benefits of leaders' formal and inter-personal relations, mainly due to their sharing of broader perspectives and the possibility of leveraging larger joint resources at their disposal. This is very much in line with the finding of the above (the second) article, as the network of leaders can easily facilitate the polling of the potentially dispersed information to reduce information asymmetry, coordinate their resources for better outcomes, and mitigate potential operational risks, both initially perceived and the actually realized later. A better matching of the opportunity exploitation requirements with firms' capabilities, priorities, and resources can be also accomplished easier by coordinating, integrating, and pooling them together as opposed to operating separately.

Second, the research of the article pointed to the higher possibility of interorganizational collaboration amongst SMEs following, or resulting from, the interpersonal relations of their leaders, which could consequently pave the road for the network of their respective SMEs to engage in collaborative opportunity recognition and subsequent collective exploitations.

Third, such leadership networks were found to hold the potential of formalizing the opportunity identification and exploitation in three functional stages and also expediting the evolutionary process of leadership in achieving more desired outcomes attributable to collaborative advantages (Kanter 1994) contributing to the evolution of leaders' competencies, including higher curiosity, leadership capabilities, and empathy, due to their inter-personal interactions.

Fourth, leaders' coordination of their inter-personal network might have arisen from the perception of reduced inherent complexities in their firms' inter-firm collaboration, and consequently mitigated the perceived risks and uncertainties associated with exploiting collective opportunities. The coordinating and joining corporate resources and aligning corporate strategies for exploiting international opportunities may have produced outcomes, which would have been beyond the reach of each SME operating independently. In short, the leadership-oriented research of this article not only complements and supports the findings of the previous article but also it points to a leadership-related strategy that can produce incremental benefits associated with collective opportunity exploration and exploitation by smaller firms, especially in the more challenging environments of international markets. 
The fourth article of this issue is co-authored by William E. Baker, Amir Grinstein, and Marcelo G. Perin and is entitled as: "The Impact of Entrepreneurial Orientation on Foreign Market Entry: the Roles of Marketing Program Adaptation, Cultural Distance, and Unanticipated Events". This article also expands upon, and complements, the arguments of earlier articles. Furthermore, it also points to the need for strategic flexibility, innovativeness, and marketing program adaptability to the diversity of international markets for attaining higher success, which smaller and younger firms my find difficult to do, especially at the outset of their internationalization.

The exploitation of foreign-market opportunity, discussed above, will inevitably involve an entry mode decision for entering into that market, which would range from low-commitment, low-risk, low-reward, and relatively short-term involvement through indirect exporting to relatively higher commitment and involvement with equally higher risks and rewards through the use of foreign direct investments (FDI). In addition to the relatively higher resource requirements of certain entry modes (e.g. FDI), putting them beyond the reaches of resource-constrained SMEs, the risk and commitment aspects of the various entry modes $^{3}$ also relate their selection to both the entrepreneurs' (or the top management team's-TMT's) risk tolerance dimension in their entrepreneurial orientation's (e.g. Covin and Slevin 1989, 1990, 1991) and the maturity of the firm in its life cycle (Etemad 2018). Similarly, the low-risk exposure and smaller resource requirement of less involved entry modes relate them with the traditional internationalization theory suggesting smaller psychic and socio-cultural distances (e.g. Johanson and Vahlne 1977, 1990), which also requires them to link and cooperate with the local distribution and marketing network(s) in the foreign markets. Generally, exporter's importing counterpart in the foreign local market is a member already, or begins to form linkages, in order to distribute the exported products in the local markets ${ }^{4}$ successfully (Boso et al. 2012; Cadogan et al. 2016; Cadogan 2012). The above relations accord very well with the earlier international network theories (Johanson and Mattsson 1987) compensating for disadvantages of "outsidership" (Johanson and Vahlne 2003, 2010) and "foreignness" (Hymer 1960; Mezias 2002; Zaheer 1995; Zaheer and Mosakowski 1997). Furthermore, most of the upper echelons of the hierarchical entry mode (e.g. Hollensen 2017) function as networks, ranging from implicit and loose (e.g. exporting, licensing, franchising, collaborative outsouring) to explicit, dense, and integrated networks (e.g. the sister-subsidiaries of MNCs), which their networking can help to compensate for their inadequacies and mitigate against intrinsic risks and uncertainties, as discussed earlier.

As for the important impact of innovation diffusion (Rogers 1957, 1983) on the success of international marketing, an earlier theory, suggesting internationalization as diffusion of innovation in international markets (e.g. Willis et al. 1991; Amine 1993), viewed adaptation of the marketing program to local conditions as strategic innovations in the firm's internationalization strategy for increasing the diffusion rate of the corresponding goods and services abroad. Stated differently, the higher entrepreneurial

\footnotetext{
${ }^{3}$ For an international marketing and strategic perspectives on entry modes, see for example, Hollensen (2017) and Kotabe and Hellsen (2016).

${ }^{4}$ The local marketing, and especially distribution, systems are generally viewed as intra-firm networks. Although their performance accords with the theoretical and benefits of networks, they function as efficient local distribution and marketing networks and joining such a local network is necessary for smaller firms using low-commitment entry modes, such as indirect exports.
} 
orientation of corporate leaders, or TMTs, is highly consistent with adapting international marketing programs in order to achieve higher penetration, higher revenues, and reduced risks of success in international markets. These arguments further suggest that marketing in general, and international marketing programs in particular, need to respectively adopt entrepreneurship, and international entrepreneurship, orientations (e.g. Etemad 2015a, b). In light of the risks and expenses associated with innovation, the above arguments raise the question of how and what motivates higher innovativeness-orientation in SMEs' internationalization and what are the end-results of such innovative actions. In summary, however, this article not only complements the earlier discussion of collaboration, entrepreneurial orientation, leadership, and networks but also serves as a planning and strategic platform for the discussion of the service innovation in the next article that follows it.

The fifth article included in this issue is co-authored by Anna Vuorio, Lasse Torkkeli1, and Liisa-Maija Sainio and is entitled as: "Service innovation and internationalization in SMEs: antecedents and profitability outcomes". By exploring the impacts of entrepreneurial orientation and innovation in internationalization of services' business models, this article presents both a complement and an extension to the above articles' discussions.

Certain characteristics of services, especially those in digital services, require special attention and pose operational challenges that are different from internationalization of goods in general and digital services in particular. In contrast to the mobility of goods that allows for their production in one location (i.e. at home or at outsourcing location(s)) in a given time period to be shipped to international locations at later time period for consumption at yet later time period, the perishability aspect of typical services requires a nearly simultaneous production and consumption of services at a given location within a short time period. Such characteristics force a departure from the traditional views of internationalization processes and push services closer to the internationalization of relatively immobile and location bound resources (for example see Etemad and Motaghi 2018, Etemad and Motaghi 2020). Furthermore, the productionconsumption simultaneity imposes other complicating requirements, if not challenges, including the following:

i. A priori preparedness for adapting on-site and in time to different consumers' requirements for delivering the expected basic value (discussed in the fourth article, above) and for achieving higher consumer satisfaction in the highly competitive global markets by creating incremental value through consumer's higher voluntary involvements;

ii. Such consumer involvements transform services to a near co-creation process with each customer at the time, which in turn, portray time, timing, and timely dimensions of services as a critical factor in the value-equation of services;

iii. The management of these time-related aspects needs a complete allowance for consumers' time and timing choices and preferences at the time; and

iv. Potential decays in the underlying knowledge of knowledge-intensive services compresses the creation, processing, and delivery times (i.e. the counter part of $\mathrm{R} \& \mathrm{D}$, production, and shipping times for goods) much beyond what has traditionally been expected. 
In short, time and user involvement have become highly essential factors. Within the above context, the authors set to explore the nature, and the drivers, of entrepreneurial internationalization in digital services. The findings of this research are based on responses of some 104 Finnish SMEs in information and communication technologies (ICTs) to an on-line questionnaire. The analysis of received responses has shed clarifying lights on the extant literature regarding the joint influences of entrepreneurial orientation (EO), human capital and service innovation on the firms' degree of internationalization (DOI), and financial performances in international markets. However, this research found more complex interactions than reported earlier in the literature. For example, different dimensions of EO exhibited different impacts - i.e., the innovativeness dimension had a positive affect on service innovation and negative impact on DOI, while the risk-taking dimension showed opposite effects - i.e., positive effect on DOI and negative impact on service innovation. Similarly, while the firm's skills and knowhow dimensions of its human capital contributed to service innovation, the firms' profitability suffered from higher degree of internationalization, which is counter to other reported findings. These results suggest that decision-making processes in entrepreneurial internationalization of service firms are more complex than anticipated. Similarly, decision-makers must search for the most optimal combinations of influential factors due to their interactive, and at times opposite, effects in different projects, locations, and time periods. As discussed earlier, certain characteristics of services, including perishability, simultaneity, co-creation, and different time and timing aspects, may not have cumulative and unidirectional impacts on internationalization and its consequent financial performance, which in turn suggests a need for deeper entrepreneurial and strategic decisions regarding focal service to be well-adapted to their context at the time. In summary, while this article pointed to service-related aspects that differ from their goods-related counterparts, it further enhanced their international performance in general and services in particular.

\section{Discussion}

This discussion will adopt the terminologies of exploration, surveying, and charting in uncharted terrains and landscapes. The five articles of this issue surveyed a somewhat different region of the entrepreneurial internationalization landscape. They also charted different pathways through the challenging peaks and hazardous valleys of this theoretical landscape that were not explored before with similar, or even different, perspectives. Consider for example that the simple research question of the second article asking: why some international opportunities are collaboratively and jointly explored and collectively exploited by some but not by others, opened a related perspective on the more basic question of information's fundamental role in the identification and exploitation of international opportunities. The collective opportunity exploration and exploitation, which deviates from the precepts of perfect competition by unrelated firms, could only be navigated by an information-based compass pointing to the hazards of fragmented and dispersed information, especially when information is generated by independent agents withholding pertinent information in self-interest, which the transaction cost theory views as "opportunistic behaviour". Such individual behavioural decisions raised a cautionary note that firms in international markets would 
function neither as perfect competitors nor as perfect collaborators. A large number of unrelated smaller firms, who need to be self-preserving, compete side-by-side with a few large, oligopolistic, powerful, and yet collaborative firms, whose oligopolistic behaviour is opportunistic (Williamson 1975, 1985). This simple cognition would suggest that internationalized and internationalizing SMEs will have to compete with agents of different size and strategic orientations, which in turn requires them to formulate highly effective strategies for the diverse environments in which they compete to ensure sustained survival. Such strategies must, therefore, include the possibility of collaborative and collective actions within the prevailing natures of competition, information and opportunistic behaviours of some collaborators and competitors, amongst many other adverse factors.

The third article of this issue explored inter-personal networking of SME executives to share characteristics similar to those in collaborative opportunity identification and collective opportunity exploitation with nearly unexpected successful outcomes. This article pointed out that, for example, a SME's executive leader, based in an emerging environment, could call upon, and possibly urge, other SME leaders to form an interpersonal network for its incremental benefits and values, which could also facilitate inter-firm collaboration and enable their possible collective opportunity exploitation, which would otherwise be difficult for each firm to attain individually and independently. Naturally, such inter-firm collaborations could offer incremental collective advantages in various strategic fronts, including communication and information, coordination for competitiveness, and collaboration and joint action for international opportunity identification and exploitation.

The fourth article of this issue pointed out a range of strategic actions, including those of larger firms' international marketing practices that follow strategically potent paths by selecting conducive modes of entry, deploying innovation, and adapting marketing plan to their environment, amongst other influential considerations, to successfully navigate through the hazardous competition of international markets. Seemingly unrelated to the arguments of the previous articles, this article is actually based on the main and substantive elements of other articles appearing before it by, for example, pointing to innovation as a potent strategy for succeeding in the international market by all firms in general, and by smaller firms in particular, especially when they are modified for competing in internationally competitive digital services.

The fifth article of this issue aimed to explore the less-chartered service territories of the entrepreneurial internationalization landscape. As discussed earlier, the substantive differences between the characteristics of goods and services distinguish service internationalization from the others. Consider, for example, that services are nearly immobile, their production and consumption are almost simultaneous, consumers are directly involved, and time and timing may have higher adverse impacts, which require local and timely innovations and adaptations in most of their routine practices from one to the next time and location. Naturally, internationalizing service SMEs can learn from the experiences of other firms' in charting a successful path through international market landscape, but their differences suggest a need for cautious experimentation with innovative ways, and at the margins, before adopting them fully. At times, such experimentation needs to be highly specific for their consumers and environments and with only cautious emulation of the so-called standardized aspects in different market, as highlighted in the article. In summary, the research topics and their collective, broad 
and complementary deliberations, implications, and lessons of the articles of this issue should be viewed as an illuminating touch, if not a guiding platform, for further research discoveries to follow.

\section{Conclusions and implications}

In light of the above discussions, the brief conclusion of this article will have to be limited to pointing out the critical importance of information that underlie nearly all internationalization efforts. The diligent, ongoing, and purposeful analyses of the supplied, or acquired, information have already become the necessary ingredients for formulating potent strategies. Similarly, the increasing power of information processing and communication technologies is transforming information that was previously viewed as "commodity" into the energizing source and indispensable resource for success in the rapidly evolving and globalizing markets, where consumers in the far corners of the world are informed about occurrence in other corners. Accordingly, a masterful driving on incomparable information speed-ways seems unavoidably necessary, and a less attentive experimentation, even on the road's margins and shoulders, may turn out costly, yet fruitfully and powerfully instructive for all others to learn.

The implication of the above discussions falls in broad categories. However, this article refrains from discussing theoretical aspects as they are more extensively discussed in each of the research-oriented articles already. Therefore, only the public policy and managerial implication will be highlighted below, as follows.

A few notable aspects of public policy have assumed higher importance recently than others. First, the public support systems need to facilitate the construction of information data structures capable of enabling internationalizing smaller firms to avoid suffering from the pitfalls of information inadequacy and information insecurity. The much-publicized recent allegations, verging on serious disputes, between the USA and China regarding unauthorized access to intellectual property is a case in point. In spite of their crucial importance, the construction and maintenance of such databases are beyond the resources of smaller firms. Second, the consultative and assisting public institutions, on which internationalizing SMEs need to rely heavily for assistance or guidance, must be equally cognizant of the emerging trend's potential impacts on SMEs in order to constructively advise them how to overcome their potential resources, time, and timing inadequacies. Third, there is a critical need for mentorship and on-site and in-time training to upgrade SME's competencies in order to augment their busy schedule and constrained resources. Fourth and finally, the broad and direct public support of innovation in advanced environments is making similar supports elsewhere increasing inevitable, especially where R\&D expenditures are the SMEs' blood-lines for attaining global competitiveness to survive in the increasingly competitive international markets.

The managerial implication of the above discussion expands over a wide area. In favour of time and space, however, only one implication needs highlighting. The lessons of traditional international economics and trade, including the comparative advantage of natural resources and cheaper labour, are losing their traditional international potency. Those older mobilizing advantages are gradually replaced by scienceand technology-related product and services based on highly advanced R\&D and 
innovation in science, engineering, and high-technology fields and knowledgeintensive industries. While internationalizing SMEs striving to become the back-bone support system of international economy, cutting-edge R\&D to support innovation are mostly, but not entirely, beyond the reaches of most relatively smaller firms. One feasible policy, which is under limited experimentation already, is a gradual entrepreneurial transformation and re-orientation of curriculum in the higher education, learning, and training institutions. Such experimentation and re-orientation may, for example, include the introduction of managerial- and social-entrepreneurship in engineering, science, and technology programs to facilitate their respective commercialization and subsequent internationalization. Conversely, a minimal exposure to advances in engineering, sciences, technology, and their respective entrepreneurial commercialization need to be injected into the curricula of relevant social and humanity disciplines to enable their graduate to participate effectively and contribute fruitfully to the rapidly changing international economy. Naturally, such re-orientation may require a redesign of certain fundamental and supporting components in the secondary, if not earlier, curricula prior to taking up post secondary and university education.

Finally, the Journal of International Entrepreneurship encourages scholars to take up the challenge of, and extending upon, some of the topics highlighted in this and previous issues of this and other progressive journals. Similarly, the journal also invites the scholarly community to reflect on, and prepare, proposals for guest-editing special issues covering the rapidly emerging issues with potentially substantive impacts on international entrepreneurship-related topics.

\section{References}

Akerlof GA (1970) The market for "lemons": quality uncertainty and the market mechanism. Q J Econ 84: 488-500

Amine LS (1993) Linking consumer behavior constructs to international marketing strategy: a comment on Wills, Samli, and Jacobs and an extension. J Acad Mark Sci 21(1):71-77

Boso N, Cadogan JW, Story VM (2012) Complementary effect of entrepreneurial and market orientations on export new product success under differing levels of competitive intensity and financial capital. Int Bus Rev 21:667-681

Cadogan JW (2012) International marketing, strategic orientations and business success: reflections on the path ahead. Int Mark Rev 29(4):340-348

Cadogan JW, Boso N, Story VM, Adeola O (2016) Export strategic orientation-performance relationship: examination of its enabling and disenabling boundary conditions. J Bus Res 69:5046-5052

Covin JG, Slevin D (1989) Strategic management of small firms in hostile and benign environments. Strateg Manag J 10(1):75-87

Covin JG, Slevin DP (1990) Content and performance of growth-seeking strategies: a comparison of small firms in high- and low technology industries. J Bus Ventur 5(6):391-412. https://doi.org/10.1016/08839026(90)90013 Jinternational ecopreneurs: The case of eco-entrepreneurial new

Covin JG, Slevin DP (1991) A conceptual model of entrepreneurship as firm behaviour. Entrep Theory Pract Fall 1991:7-25

Dana LP, Etemad H, Wright R (2001) Symbiotic business networks: collaboration between small and large firm. Thunderbird Int Bus Rev 43(4):481-500 https://doi.org/10.1016/j.ibusrev.2018.03.003

DeClercq D, Sapienza H, Crijins H (2005) Internationalization of SMEs: the role of organizational learning effort and entrepreneurial orientation. Small Bus Econ 24:1-28

Deligianni I, Dimitratos P, Petrou A, Aharoni Y (2015) Entrepreneurial orientation and international performance: the moderating effect of decision-making rationality. J Small Bus Manag 54(2):462-480. https://doi.org/10.1111/jsbm.12152 
Dew N, Velamuri SR, Venkataraman S (2003) Dispersed knowledge and an entrepreneurial theory of the firm. J Bus Ventur V19:659-679. https://doi.org/10.1016/j.jbousvent.2003.09.004

Etemad H (2015a) Preface to the special issue on international opportunities. J Int Entrep 13:169-172. https://doi.org/10.1007/s10843-015-0159-3

Etemad H (2015b) The promise of a potential theoretical framework in international entrepreneurship: an entrepreneurial orientation-performance relation in internationalized context. J Int Entrep 13:89-95

Etemad H (2018) Early strategic heritage: the carryover effect on entrepreneurial firm's life cycle. J Int Entrep 16:441-455. https://doi.org/10.1007/s10843-018-0240-9

Etemad H, Motaghi H (2018) Internationalization pattern of creative-cultural events: Two cases from Canada, international business review 27(5): 1033-1044. https://doi.org/10.1016/j.ibusrev.2018.03.003

Etemad H, Motaghi H (2020) Internationalization of location-bound resources: two Canadian cases in Etemad. In: Evers HN, Kock S (eds) Inside born globals, International New Ventures and Rapidly Internationalizing Enterprises. Edward Elgar Publishing Ltd, Northampton

Etemad H, Wu P-C (2013) Revisiting aspects of born globals: young Canadian SMEs growing rapidly and becoming born globals. In: Etemad $\mathrm{H}$ (ed) Current issues in international entrepreneurship. Edward Elgar Publishing Ltd, Northampton, pp 13-37 (ISBN: 978-1-78100-318-3)

Etemad H, Wright R, Dana LP (2001) Symbiotic business networks: collaboration between small and large firms. Thunderbird Int Bus Rev 43(4):481-500

Foss NJ (1993) More on Knight and the theory of the firm. Manag Decis Econ 14:269-276

Gnizy I, Baker WE, Grinstein A (2014) Proactive learning culture: a dynamic capability and key success factor for SMEs entering foreign markets. Int Mark Rev 31(5):477-505

Granovetter M (1985) Economic action and social structure: the problem of embeddedness. Am J Sociol 91(3):481-510

Hollensen S (2017) Global marketing, Seventh edn. Pearson Education Limited, UK, pp 370-435

Hong J, Song TH, Yoo S (2013) Paths to success: how do market orientation and entrepreneurship orientation produce new product success? J Prod Innov Manag 30(1):44-55

Hymer SH (1960) The international operations of national firms: a study of direct foreign investment. $\mathrm{PhD}$ dissertation, MIT (published posthumously. The MIT Press, 1976. Cambridge, Mass)

Johanson J, Mattsson L-G (1987) Interorganizational relations in industrial systems: a network approach compared with the transaction cost approach. Int Stud Manag Organ 17(1):34 48. https://doi.org/10.1080 /00208825.1987.11656444

Johanson J, Vahlne E (1977) The internationalization process of the firm - a model of knowledge development and increasing foreign market commitments. J Int Bus Stud 8(1):23-32

Johanson J, Vahlne E (1990) The mechanism of internationalization. Int Mark Rev 7(4):11-24

Johanson J, Vahlne E (2003) Business relationship learning and commitment in the internationalization process. J Int Entrep 1:83-102

Johanson J, Vahlne E (2010) Markets as networks: implications for strategy-making. J Acad Mark Sci 39(4): 484-491

Kanter RM (1994) Collaborative advantage. Harvard Business Rev 1994:96-108

Keen CH, Etemad H (2011) Rapidly-growing firms and their main characteristics: a longitudinal study from United States. Int J Entrep Ventur 3(4):344-358

Keen CH, Etemad H (2012) Rapid-growth and rapid internationalization of smaller enterprises from Canada. Manag Decis 50(4):569-590. https://doi.org/10.1108/00251741211220138

Knight FH (1957) Risk, uncertainty, and profit, 8th edn. Kelley \& Millman, New York

Knight GA, Cavusgil ST (2004) Innovation, organizational capabilities, and the born-global firm. J Int Bus Stud 35(2):124-141. https://doi.org/10.1057/palgrave.jibs.8400071

Kotabe M, Hellsen K (2016) Global marketing management, Eighth edn. Wiley and Sons, NY, pp 306-336

Langlois RN, Cosgel MM (1993) Frank Knight on risk, uncertainty, and the firm: a new interpretation. Econ Inq 31:456-465

Lumpkin GT, Dess GG (1996) Clarifying the entrepreneurial orientation construct and linking it to performance. Acad Manag Rev 21(1):135-172

McDougall PP (1989) International versus domestic entrepreneurship: new venture strategic behavior and industry structure. J Bus Ventur 4(6):387-400

McDougall PP, Oviatt BM (2000) International entrepreneurship: the intersection of two research paths. Acad Manag J 43(5):902-906

McDougall PP, Shane S, Oviatt BM (1994) Explaining the formation of international new ventures: the limits of theories from international business research. J Bus Ventur 9(6):469-487. https://doi.org/10.1016 /0883-9026(94)90017-5 
Mezias JM (2002) How to identify liabilities of foreignness and assess their effects on multinational corporations. J Int Manag 8(2002):265-282

Morgan RE, Strong CA (2003) Business performance and dimensions of strategic orientation. J Bus Res 56(3):163-176

Oviatt BM, McDougall PP (1994) Toward a theory of international new ventures. J Int Bus Stud 25(1):45-64. https://doi.org/10.1057/palgrave.jibs.8490193

Oviatt BM, McDougall PP (1995) Global start-ups: entrepreneurs on a worldwide stage. Management 9(2): $30-44$

Pisano GP (2015) A normative theory of dynamic capabilities: connecting strategy, know-how, and competition. HBS Working Paper 16-036. https://hbswk.hbs.edu/item/a-normative-theory-ofdynamiccapabilities-connecting-strategy-know-how-and-competition. Accessed on 8 February 2018

Renkoa M, Freeman MJ (2017) How motivation matters: conceptual alignment of individual and opportunity as a predictor of starting up. J Bus Ventur Insights 8:56-63

Rodriguez Cano C, Carrillat FA, Jaramillo F (2004) A meta-analysis of the relationship between market orientation and business performance: evidence from five countries. Int J Res Mark 21:179-200

Rogers EM (1957) Personality correlates of the adoption of technological practices. Rural Sociol 22:267-268

Rogers EM (1983) Diffusion of innovation. Free Press, New York

Romanello R, Chiarvesio (2019) Early internationalizing firms: 2004-2018. J Int Entrep 17:172-219

Teece D (2014) A dynamic capabilities-based entrepreneurial theory of the multinational enterprise. J Int Bus Stud 45(1):8-37

Teece D, Pisano G, Shuen A (1997) Dynamic capabilities and strategic management. Strateg Manag J 18:509_ 533

Williamson OE (1975) Markets and hierarchies: analysis and antitrust implications. Basic Books, New York Williamson OE (1985) The economic institutions of capitalism. Free Press, New York

Willis JR, Samli AC, Jacobs L (1991) Developing global products and marketing strategies: a construct and a research agenda. J Acad Mark Sci 19(Winter):1-10

Zaheer S (1995) Overcoming the liability of foreignness. Acad Manag J 38(2):341-363

Zaheer S, Mosakowski E (1997) The dynamics of liabilities of foreignness: a global study of firms' survival in financial services. Strateg Manag J 18(6):439-464

Publisher's note Springer Nature remains neutral with regard to jurisdictional claims in published maps and institutional affiliations. 